\title{
Skeletal Muscle Histidine Containing Dipeptide Contents are Increased in Freshwater Turtles (Chrysemys picta bellii) with Cold-Acclimation
}

Running Title: $H C D$ content of freshwater turtles.

Eimear Dolan ${ }^{a}$; Daniel E. Warren ${ }^{b}$; Roger C. Harris ${ }^{c}$; Craig Sale ${ }^{d}$; Bruno Gualano ${ }^{a . e}$; Bryan Saunders ${ }^{a, f}$.

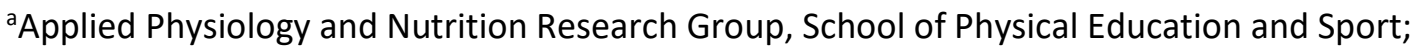
Rheumatology Division; Faculdade de Medicina FMUSP, Universidade de Sao Paulo, Sao Paulo, SP, BR.

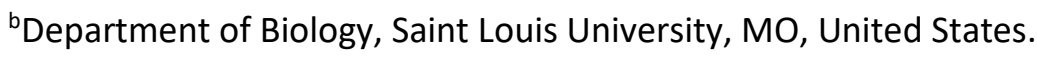

'Junipa Ltd, Newmarket, United Kingdom.

${ }^{\mathrm{d}}$ Musculoskeletal Physiology Research Group, Sport Health and Performance Enhancement Research

Kingdom.

${ }^{\mathrm{e} F o o d}$ Research Centre, University of Sao Paulo, Sao Paulo, Brazil. Brazil.

\section{Corresponding Authors:}

Dr. Bryan Saunders

Faculty of Medicine

University of Sao Paulo, SP, BR

E-mail: drbryansaunders@outlook.com
Dr. Daniel Warren Department of Biology Saint Louis University, St. Louis, MO, USA E-mail: Daniel.Warren@slu.edu
22

Key-Words: alphastat; $\mathrm{pH}$; acid-base; carnosine; buffering; hypoxia; hibernation.

\section{Highlights:}

- $\mathrm{pH}$ regulation is a major challenge for overwintering freshwater turtles.

- Histidine containing dipeptides are important intracellular buffers.

- Turtles acclimated to $3^{\circ} \mathrm{C}$ had higher HCD content than those at $20^{\circ} \mathrm{C}$.

- HCDs may be important $\mathrm{pH}$ regulators in cold-acclimated turtles. 


\section{Abstract:}

30 Freshwater turtles found in higher latitudes can experience extreme challenges to acid-base 31 homeostasis while overwintering, due to a combination of cold temperatures along with the potential 32 for environmental hypoxia. Histidine containing dipeptides (HCDs; carnosine, anserine and balenine) 33 may facilitate $\mathrm{pH}$ regulation in response to these challenges, through their role as $\mathrm{pH}$ buffers. We 34 measured the HCDs content of three tissues (liver, cardiac muscle and skeletal muscle) from the 35 anoxia-tolerant painted turtle (Chrysemys picta bellii) acclimated to either 3 or $20^{\circ} \mathrm{C}$. HCDs were 36 detected in all tissues, with the highest content shown in the skeletal muscle. Turtles acclimated to $373^{\circ} \mathrm{C}$ had more $\mathrm{HCD}$ in their skeletal muscle than those acclimated to $20^{\circ} \mathrm{C}$ (carnosine $=20.8 \pm 4.5$ vs $\left.3812.5 \pm 5.9 \mathrm{mmol} \cdot \mathrm{kg} \mathrm{DM}^{-1} ; \mathrm{ES}=1.59(95 \% \mathrm{Cl}: 0.16-3.00), \mathrm{P}=0.013\right)$. The higher $\mathrm{HCD}$ content observed 39 in the skeletal muscle of the cold-acclimated turtles suggests a role in acid-base regulation in response 40 to physiological challenges associated with living in the cold, with the increase possibly related to the 41 temperature sensitivity of carnosine's dissociation constant and buffering power of the skeletal 42 muscle during anoxic submergence. 


\section{INTRODUCTION}

The ability to maintain acid-base balance within homeostatic limits is essential for maintaining cellular function (1). Acid-base homeostasis is constantly challenged by various internal and external factors. For example, anaerobic metabolism is required for continued ATP regeneration when turnover exceeds the oxidative capacity of the cell. This results in hydrogen cation $\left(\mathrm{H}^{+}\right)$accumulation and increased metabolic acidosis (2), which has adverse consequences for numerous cellular processes, including reduced glycolytic enzyme activity, inhibition of oxidative phosphorylation and impaired phosphorylcreatine $(\mathrm{PCr}$ ) resynthesis (3-5). To avoid these adverse consequences, living organisms have evolved a diverse range of $\mathrm{pH}$ regulatory strategies. Intracellular buffers, such as bicarbonate, phosphates, proteins and histidine containing dipeptides (HCDs), provide an important "first line of defence" against intracellular pH perturbations. Simultaneously, "dynamic buffering" is the process by which excess $\mathrm{H}^{+}$is removed from the cell via $\mathrm{Na} / \mathrm{H}^{+}$exchangers and monocarboxylate transporters $(6,7)$.

In vertebrates, the HCDs carnosine (beta-alanyl-L-histidine), along with its methylated analogues balenine (beta-alanyl-1-methyl-L-histidine) and anserine (beta-alanyl-3-methyl-L-histidine), are important intracellular buffers with acid dissociation constants ( $\mathrm{pKa}$ 's) at physiological temperatures (i.e., $36^{\circ} \mathrm{C}$ ) that render them ideally placed to buffer across physiological $\mathrm{pH}$ ranges (8) - for skeletal muscle this is approximately $7.1-6.5(9,10)$. Previous studies indicate that these dipeptides are abundant in the skeletal muscle of species with a large capacity for anaerobic energy metabolism, and that have adapted to tolerate high acid loads (11-13). These species include sprinters, such as thoroughbred racehorses and greyhounds (14); avian species with a limited ability for aerobically fueled flight, such as chickens $(15,16)$; and aquatic mammals that undergo prolonged periods of hypoxia while diving, such as blue or fin whales (17).

North American pond turtles have a remarkable tolerance to hypoxia (to the point of anoxia), during which they experience major challenges to $\mathrm{pH}$ homeostasis (18). As such, they represent a fascinating model to investigate $\mathrm{pH}$ buffering. During winter, many of these turtles, especially those found in higher latitudes, are forced to overwinter in anoxic water at the bottom of small ponds and swamps. The western painted turtle (Chrysemys picta bellii) can survive anoxia at $3^{\circ} \mathrm{C}$ for more than 170 days, despite oxygen levels being undetectable $(18,19)$. This remarkable ability to withstand anoxia results from three main evolutionary adaptations: extreme metabolic suppression, large tissue glycogen stores, and a marked capacity to withstand metabolic acidosis $(20,21)$. Painted turtles can tolerate very high circulating lactate, with plasma levels of up to $200 \mathrm{mM}$ recorded (21), while blood $\mathrm{pH}$ falls to $\sim 7.2$ from normal $\mathrm{pH}$ of 8.1 at $3^{\circ} \mathrm{C}(18)$, representing a remarkable capacity for buffering and $\mathrm{pH}$ regulation. To put this into context, humans undertaking exhaustive exercise experience plasma lactate increases of $14-18 \mathrm{mM}$, concomitant to a large export of $\mathrm{H}^{+}$out of the muscle, which generally leads to a reduction in $\mathrm{pH}$ from approximately 7.4 to 7.1. Turtles' buffering ability is largely achieved via the shell (22), which buffers $\mathrm{pH}$ by releasing calcium and magnesium carbonates, and via the direct uptake of lactate and $\mathrm{H}^{+}$by the shell (23). Less certain in these species is the contribution of intracellular physicochemical buffers in unmineralized tissues, such as the HCDs, which have previously been reported to be abundant in species who experience large challenges to acid-base regulation (13).

In addition to the challenges that extreme hypoxia poses, these ectothermic vertebrates also hibernate in near freezing conditions, which also has implications for $\mathrm{pH}$ regulation, particularly with regards to the charge state of histidyl residues within proteins. Reeve's alpha-stat hypothesis states that ectotherms shift intracellular and extracellular $\mathrm{pH}$ according to temperature in order to maintain constant imidazole ionization, also called alpha $(24,25)$. HCDs comprise the majority of these 
intracellular imidazole compounds (11) and as such are likely to contribute toward maintenance of alpha. Therefore, painted turtles are exposed to two major acid-base stressors while hibernating during winter - anoxia and low temperatures. Theoretically HCD content may contribute toward defending against both of these stressors, but little is currently known about the HCD content of these ectothermic vertebrates, nor whether these contents are affected by temperature. The aim of this exploratory study, therefore, was to determine the skeletal muscle, liver and heart HCD content of freshwater western painted turtles who were acclimated to either $3^{\circ} \mathrm{C}$ or $20^{\circ} \mathrm{C}$.

\section{Animals:}

Ten adult painted turtles (Chrysemys picta bellii; Niles Biological, Sacramento, CA, USA) of both sexes were acclimated to either $3^{\circ} \mathrm{C}(n=5)$ or $20^{\circ} \mathrm{C}(n=5)$. Prior to temperature acclimation they were maintained for 1-3 months in large tanks filled with partially dechlorinated St. Louis municipal tap water under natural Minnesota photoperiod. The turtles had access to a drying platform, an incandescent light bulb for basking, and a 10W UVB light for nutritional purposes. Air and water temperatures were maintained between $18-22^{\circ} \mathrm{C}$. During this time, turtles were fed commercial turtle pellets ad libitum three times per week. For the temperature acclimation, the $20^{\circ} \mathrm{C}$ turtles $(n=5)$ were transferred to an 80 -liter temperature-controlled aquarium with water temperature thermostatted to $20^{\circ} \mathrm{C}$ (YSI Model 72) and were held there, without food, for $36-48$ hours. The $3^{\circ} \mathrm{C}$ turtles $(n=5)$ were placed into an $\sim 80$-liter aquarium with water temperature initially thermostatted to $20^{\circ} \mathrm{C}$. The set temperature was lowered by $2^{\circ} \mathrm{C}$ per day for just over 8 days until it reached $3^{\circ} \mathrm{C}$, and then held there for an additional two weeks. The turtles were not fed during the acclimation period. All procedures were approved by the Saint Louis University Institutional Animal Care and Use Committee (IACUC protocol 2198).

\section{Tissue sampling and preparation}

Turtles were euthanized by rapid decapitation. After the plastron was removed with a bone saw, samples of ventricle, liver and pectoralis muscle were removed and immediately flash-frozen with freeze clamps pre-chilled in liquid nitrogen, and then stored at $-80^{\circ} \mathrm{C}$ until analysed. All samples were subsequently lyophilised and powdered before extraction was performed using perchloric acid $\left[\mathrm{HClO}_{4}\right]$, EDTA and potassium bicarbonate $\left[\mathrm{KHCO}_{3}\right](26)$. The neutralised supernatant was collected using a centrifugal filter $(0.2 \mu \mathrm{m})$, checked to ensure a pH close to 7 and then stored at $-80^{\circ} \mathrm{C}$ until high-pressure liquid chromatographic (HPLC) analysis.

\section{Chromatographic determination of histidine-containing dipeptides}

The HCD content was determined by HPLC (Hitachi, Hitachi Ltd., Tokyo, Japan), as per Mora et al. (27) using an Atlantis HILIC silica column $(4.6 \times 150 \mathrm{~mm}, 3 \mu \mathrm{m}$; (Waters, Massachusetts, USA). All chromatography was conducted at room temperature. Samples were analysed in duplicate and injected via an auto sampler using a loop injection method. Two mobile phases were used. Mobile phase A: $0.65 \mathrm{mM}$ ammonium acetate, in water/acetonitrile (25:75) (v/v). Mobile phase B: $4.55 \mathrm{mM}$ ammonium acetate, in water/acetonitrile (70:30). The $\mathrm{pH}$ of both solutions was adjusted to 5.5 using hydrochloric acid and thereafter filtered under vacuum through a $0.2 \mu \mathrm{m}$ filter membrane. The separation condition comprised a linear gradient from 0 to $100 \%$ of solvent B in $13 \mathrm{~min}$ at a flow rate of $1.4 \mathrm{~mL} \cdot \mathrm{min}^{-1}$. Separation was monitored using an ultraviolet detector at a wavelength of $214 \mathrm{~nm}$. 
The area under the curve (AUC) for carnosine was obtained and used to estimate the content by comparison to standards of 100,250,500 and $1000 \mu \mathrm{M}$. The in-house variability of the extraction and analysis methods is 4.0 and $2.5 \%$ (28). Another peak in close proximity to carnosine was detected in several samples, which was likely to be balenine and/or anserine (27). To determine which of these it was, several samples were spiked with anserine, and the subsequent retention times showed anserine not to be the unidentified peak (retention times, carnosine: $8.5 \mathrm{~min}$; unidentified peak: 9 min; anserine: $9.5 \mathrm{~min}$ ), meaning that it was balenine (27). Balenine standards were unavailable so quantification could not be performed. Instead, balenine is reported as AUC and relative to carnosine AUC.

\section{Data analysis}

Data were analysed using the SAS statistical package (SAS ${ }^{\circledR}$ University Edition, SAS Institute Inc., USA), and are presented as mean $\pm 1 S D$. HCD content (total HCD AUC and carnosine content mmol $\cdot \mathrm{kg} \mathrm{DM}^{-1}$ ) were analysed using mixed model analysis with animals assumed as a random factor and tissue ( 3 levels; liver/ventricle/m. pectoralis) and environment ( 2 levels; 3 or $20^{\circ} \mathrm{C}$ ) assumed as fixed factors. Tukey-Kramer adjustments were performed when a significant $F$ value was obtained. Results were interpreted according to the statistical probabilities of rejecting the null hypothesis $(\mathrm{HO})$ and in the following categories: $p>0.1$ : no evidence against $\mathrm{HO}$; $0.05<p<0.1$ : weak evidence against $\mathrm{HO} ; 0.01$ $<\mathrm{p}<0.05$ : some evidence against $\mathrm{HO} ; 0.001<\mathrm{p}<0.01$ : strong evidence against $\mathrm{HO} ;<\mathrm{p}<0.001$ : very strong evidence against $\mathrm{HO}(29)$. Effect sizes (ES) were calculated as the mean difference between the two groups of turtles, divided by the pooled standard deviation and are reported alongside their $95 \%$ confidence interval. The theoretical buffering contribution of the observed HCD content for a reduction of $0.6 \mathrm{pH}$ units was calculated using a derivation of the Henderson Hasselbalch equation (14) namely: $\beta_{\mathrm{HCD}}=\left\{[\mathrm{HCD}] /\left(1+10^{\wedge(\mathrm{pHi}-\mathrm{pKa})}\right)\right\}-\left\{[\mathrm{HCD}] /\left(1+10^{\wedge(\mathrm{pHi}-\mathrm{pKa})}\right)\right\}$. For this calculation we assumed the physiologically relevant pHi range was 7.1 down to 6.5 at $20^{\circ} \mathrm{C}(30)$ and 7.4 to 6.8 at $3^{\circ}(31)$ and pKa's for carnosine of 6.702 and 7.209 at $20^{\circ}$ and $3^{\circ} \mathrm{C}(32)$.

\section{RESULTS}

\section{HCD Content}

HCDs were detected in all examined tissues (Figure 1, Panel A). Carnosine was found in the $m$. pectoralis $\left(16.09 \pm 7.00 \mathrm{mmol}^{\circ} \cdot \mathrm{kgMM}^{-1}\right)$ and balenine in the liver, whilst both balenine and carnosine $\left(6.08 \pm 2.95 \mathrm{mmol} \cdot \mathrm{kgDM}^{-1}\right)$ were found in the ventricle (contents reported as the mean of all animals). Visual inspection of the chromatograms suggested that very small amounts of balenine were present in two of the $m$. pectoralis samples and very small amounts of carnosine in two of the liver samples, although these were below the limits of interpolation and quantification of the detection software. HCDs were more abundant in $m$. pectoralis than in either of the other two tissues $(p \leq 0.001)$, which did not differ in their total HCD content ( $p=0.813$; Figure 1B). There was weak evidence that temperature influenced the total HCD content (expressed as combined AUC) combining all tissues ( $p$ $=0.092)$, and there was some evidence of a tissue by temperature interaction $(p=0.021)$. Post-hoc analysis revealed no differences between temperature conditions for liver $(p=1.00)$ or ventricle $(p=$ 0.99), but there was some evidence that the turtles acclimated to $3^{\circ} \mathrm{C}$ had a higher total $m$. pectoralis $\mathrm{HCD}$ content than those kept at $20^{\circ} \mathrm{C}(p=0.023)$. Turtles maintained at $3^{\circ} \mathrm{C}$ had a carnosine content of $20.8 \pm 4.5 \mathrm{mmol} \cdot \mathrm{kg} \mathrm{DM}^{-1}$, compared to a content of $12.5 \pm 5.9 \mathrm{mmol}^{\circ} \cdot \mathrm{kg} \mathrm{DM}^{-1}$ in those maintained at $20^{\circ} \mathrm{C}(\mathrm{ES}=1.59(95 \% \mathrm{Cl}: 0.16-3.00), \mathrm{p}=0.013$; Figure 1, Panel $\mathrm{B})$. This equated to a buffering 
bioRxiv preprint doi: https://doi.org/10.1101/2021.05.31.446418; this version posted May 31,2021 The copyright holder for this preprin (which was not certified by peer review) is the author/funder, who has granted bioRxiv a license to display the preprint in perpetuity. It is made available under aCC-BY-ND 4.0 International license.

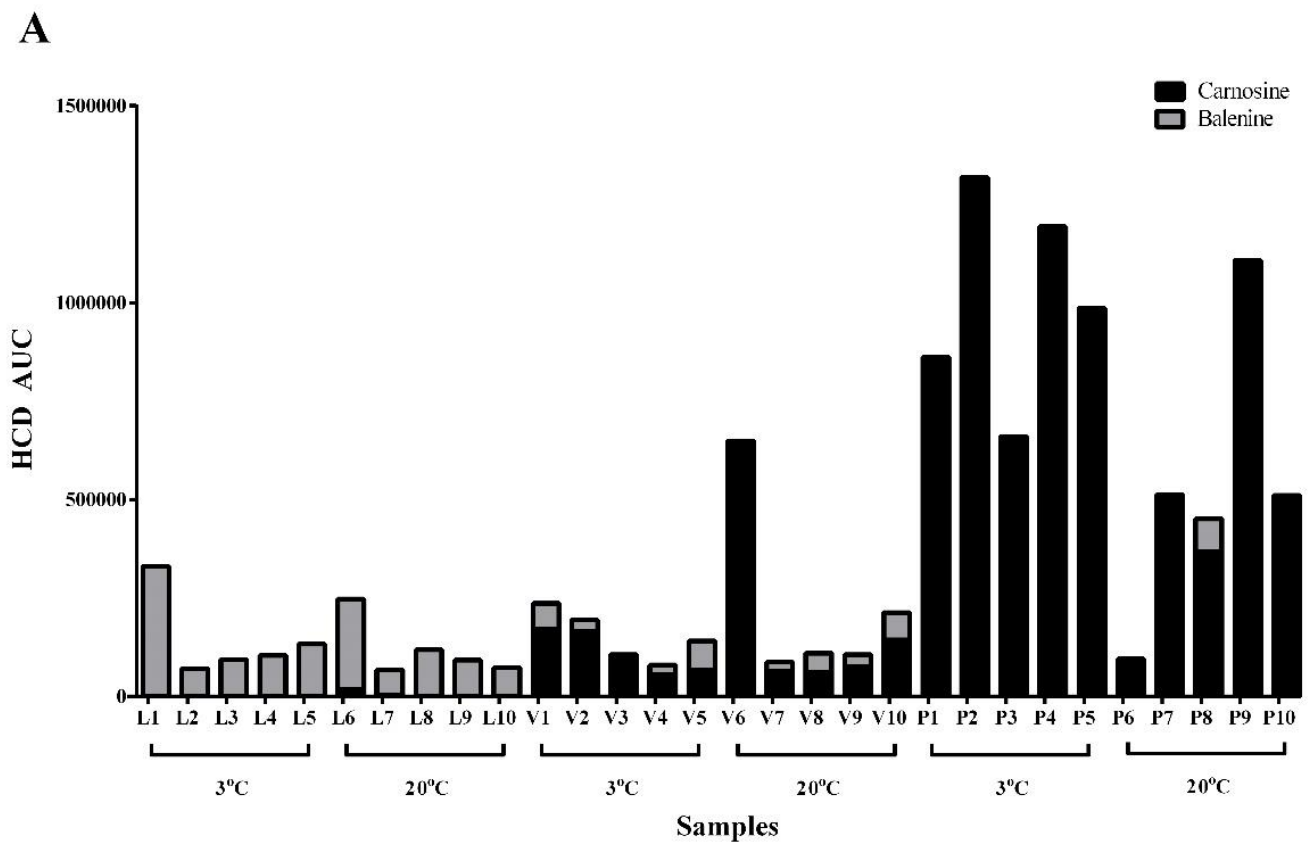

B

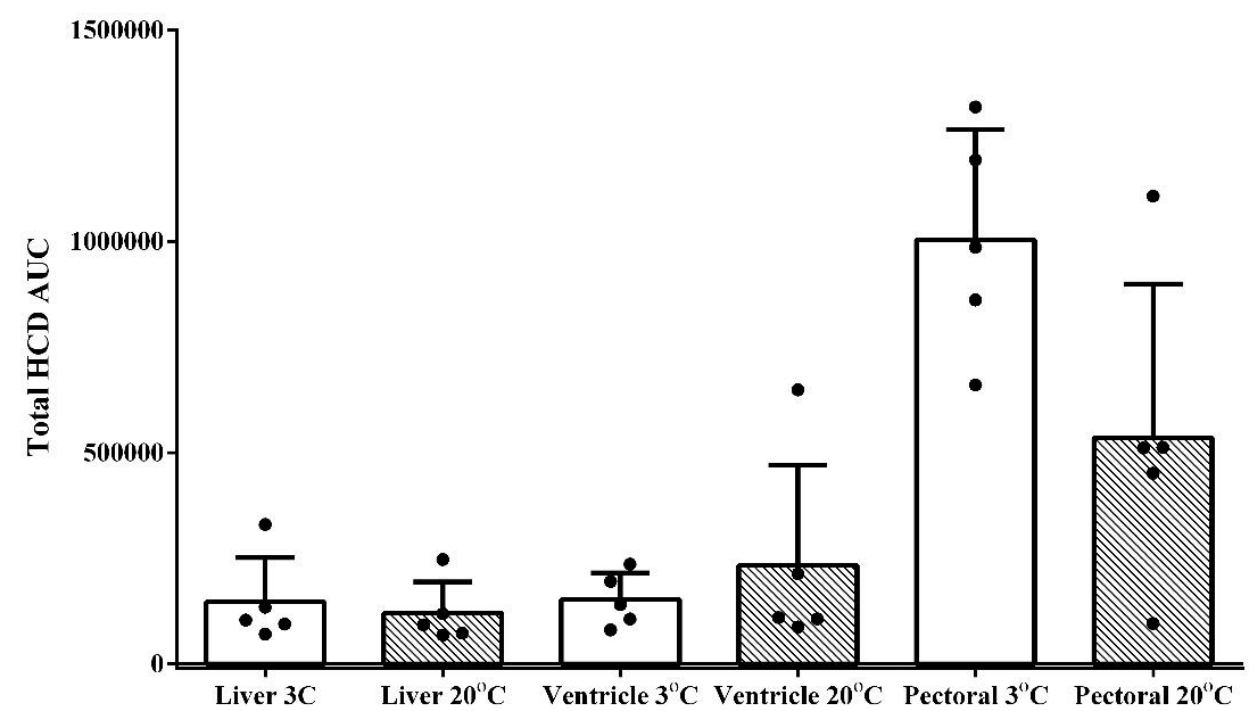

Figure 1: Panel A: Individual area under the curve (AUC) HCD content of the turtles maintained at 3 and $20^{\circ} \mathrm{C} . \mathrm{L}=$ liver; $\mathrm{V}=$ ventricle and $\mathrm{P}=$ Pectoralis. Panel B: Mean area under the curve (AUC) HCD content of turtles maintained at 3 or $20^{\circ} \mathrm{C}$. 


\section{DISCUSSION}

186 The purpose of this study was to determine the intracellular HCD content of anoxia-tolerant painted turtles acclimated to either 3 or $20^{\circ} \mathrm{C}$. The turtles acclimated to $3^{\circ} \mathrm{C}$ had a higher m.pectoralis carnosine content than those maintained at $20^{\circ} \mathrm{C}$, while liver and cardiac $\mathrm{HCD}$ contents were not different. This indicates that intramuscular carnosine content may be instrumental in the adaptive response of these ectotherms to a cold environment.

HCD content varies widely between species and is abundant in the skeletal muscle of those with highly evolved capacities to withstand exercise-induced or environmental hypoxia $(11,13)$. As such, it might have been expected to observe very high HCD levels in painted turtles, given their remarkable capacity to withstand extreme hypoxia (to the point of anoxia), during which they accumulate blood lactate to levels approaching $200 \mathrm{mM}$ (21). This was not, however, the case and the painted turtles investigated herein had low HCD contents when considered within the context of other species (see figure 2). Even compared with other reptiles, painted turtles have unremarkable HCD contents, with comparable levels to those reported in green sea turtles (Chelonia mydas; Suborder Cryptodira) and eastern longnecked turtles (Chelodina longicollis; Suborder Pleurodira) $(33,34)$. The reason for this relatively low intramuscular carnosine content, despite the extreme challenges to acid-base regulation that these animals face, is unclear, but it could relate to the large availability of other mineralized buffers, along with the length of time across which acidosis occurs in this species. Turtles, and painted turtles in particular, can use the calcium and magnesium carbonate stored in their mineralized tissues (i.e., shell and skeleton) to buffer the acidosis that slowly accumulates over months (23). In contrast, the acidosis incurred by the sprint or diving animals previously reported to be abundant in HCDs $(12,13)$ is more acute, and occurs when intracellular $\mathrm{H}^{+}$generation is in excess of that which can be actively transported out of the cell. As such, intracellular buffering agents, including tissue HCD contents, may have a greater physiological importance for these animals as opposed to turtles, who experience a more gradual and prolonged acid base stressor while hibernating. In support of this assertion are data suggesting relatively low non-bicarbonate buffering capacities in turtles (35) compared to cetaceans, such as whales (36), who experience the dual challenges of locomotion and hypoxia while diving. In contrast, turtles remain largely stationary when hibernating in anoxic conditions and appear to have solved the buffering problem by exporting $\mathrm{H}^{+}$to the circulation, where it is subsequently buffered by calcium and magnesium carbonates released by the shell, or taken up directly (as lactate and $\mathrm{H}^{+}$) and buffered by the shell (23).

The higher skeletal muscle carnosine content observed in the cold-acclimated turtles implies a regulatory role for the HCDs in adapting to this stressor. Skeletal muscle forms the largest mass of unmineralized tissue in the turtle, so higher muscle carnosine content could have quantitatively important consequences for acid-base regulation, assuming that it is the predominant histidylated peptide contained therein. Turtles have long been known to be alpha-stat regulators, which means they decrease their $\mathrm{PCO}_{2}$ in order to increase their relative alkalinity for the purpose of defending the dissociation fraction (alpha) of the imidazole functional groups in histidine residues within their proteome, thereby preserving their charge and conformational states (24). Based on Reeves (24), the the small change in MCarn observed in the present study would have minimal impacts on intracellular $\mathrm{pH}$ or $\mathrm{PCO}_{2}$. Thus, the most important effect will be on the buffering power of the muscle. The pKa of carnosine is increased in colder conditions $\left(7.209\right.$ at $3^{\circ} \mathrm{C}$ vs 6.702 at $\left.20^{\circ} \mathrm{C}\right)$ which would contribute to the maintenance of the increased alkalinity, given that each temperature-specific $\mathrm{pKa}$ is within the mid-range of the assumed $\mathrm{pHi}$ at $3^{\circ} \mathrm{C}(7.4-6.8)$ and $20^{\circ} \mathrm{C}\left(7.1-6.5^{\circ} \mathrm{C}\right)$. Estimation of the theoretical buffering contribution of the observed MCarn content indicated a higher buffering capacity in the cold-acclimated turtles, again suggesting that this dipeptide may play an important role in acid-base 
regulation at this temperature. Increases of the magnitude observed herein are roughly comparable to those observed in humans in response to commonly used BA dosing protocols (38), and would necessitate either a large increase in carnosine synthesis, a large reduction in carnosine degradation, or perhaps a combination of both (37). Given that no external BA source was available to these turtles, increased synthesis could only have occurred via increased endogenous production, alongside an increase in carnosine synthase activity. This seems unlikely considering the time-periods that were investigated, and a reduced degradation rate may have contributed (at least in part) to the observed increases. This is, of course, speculative and further research is required both to confirm our findings, and to explore the biokinetics of cold-induced MCarn increases in these ectothermic vertebrates. It is also important to highlight that the numbers of turtles included in this study was small ( $n=5$ per group), which does increase the risk of sampling error. As such, caution must be applied when interpretating the reported magnitude of increase.

Although the importance of the HCDs to intracellular acid-base regulation is well-recognised, these dipeptides are also thought to contribute toward a number of other biological processes that may be relevant to the dual challenges of anoxia and cold temperatures. Carnosine may play a role in metal ion chelation, antioxidant activity, protein carbonylation and glycoxidation, nonpolysomal proteolysis, and nitric oxide metabolism (18). Of these, carnosine's antioxidant activity may be most relevant to severely hypoxic and anoxic tissues like those in overwintering turtles, which, theoretically, experience an increase in ROS from xanthine oxidase activity with the reperfusion of oxygen during spring emergence (39). The higher carnosine content, as observed in the cold-acclimated turtles, could, theoretically, increase the antioxidant activity of skeletal muscle and reduce any ROS-mediated injury that might occur during tissue reperfusion.

An interesting finding was the distinct HCD profile within the different tissues. It was unsurprising that skeletal muscle had the largest HCD content, as it has previously been estimated that approximately 99\% of the total carnosine is located in this tissue (11). In studies of this kind, three HCD forms are commonly detected in different species, namely carnosine, and its methylated analogues balenine and anserine. Most species contain at least two HCD forms and this varies largely between phylogenetically distinct species, but is similar within the same, or congeneric, species. Only carnosine and balenine were identified in painted turtles, with the latter being absent in skeletal muscle. This is similar to green sea turtles and leatherback turtles (both Cryptodira) (33), but different from eastern long-necked turtles (Pleurodira) (34). The uniformity of HCD distribution of different types in different tissues implies that they may exert type- or tissue-specific effects. Herein, turtles had small amounts of balenine in the liver (AUC), greater amounts of carnosine in the skeletal muscle and a mixture of both balenine and carnosine in the ventricle. The significance of this variation is uncertain, but some biological differences have been reported between the HCD analogues. For example, each HCD has a subtly different pKa (estimated to be $7.03,7.04$ and 6.83 for anserine, balenine and carnosine at mammalian temperatures, i.e., $\sim 37^{\circ} \mathrm{C}$ ), while distinct anti-radical effects of the different $\mathrm{HCD}$ analogues have also been suggested $(40,41)$. The functional relevance of these subtle physiological differences is unknown and represents an interesting avenue for future research.

In conclusion, we measured HCDs in the ventricle, liver and m.pectoralis of the freshwater turtle, with balenine predominating in the liver, carnosine in the skeletal muscle and a mixture of the two in cardiac tissue. Tissue HCD content was relatively low compared to other species with large buffering requirements, implying that overall intracellular buffering may not make a substantial contribution to these turtles' remarkable capacity to withstand oxygen deprivation. Nonetheless, the HCD content of the $m$. pectoralis was higher in those turtles that were acclimated to $3^{\circ} \mathrm{C}$, as opposed to $20^{\circ} \mathrm{C}$, which 
bioRxiv preprint doi: https://doi org/101101/2021.05 31.446418; this version posted May 31, 2021. The copyright holder for this preprin (which was not certified by peer review) is the author/funder, who has granted bioRxiv a license to display the preprint in perpetuity. It is made available under aCC-BY-ND 4.0 International license.

implies a regulatory role for the HCDs in responding to challenges to acid-base homeostasis that occur at colder temperature.

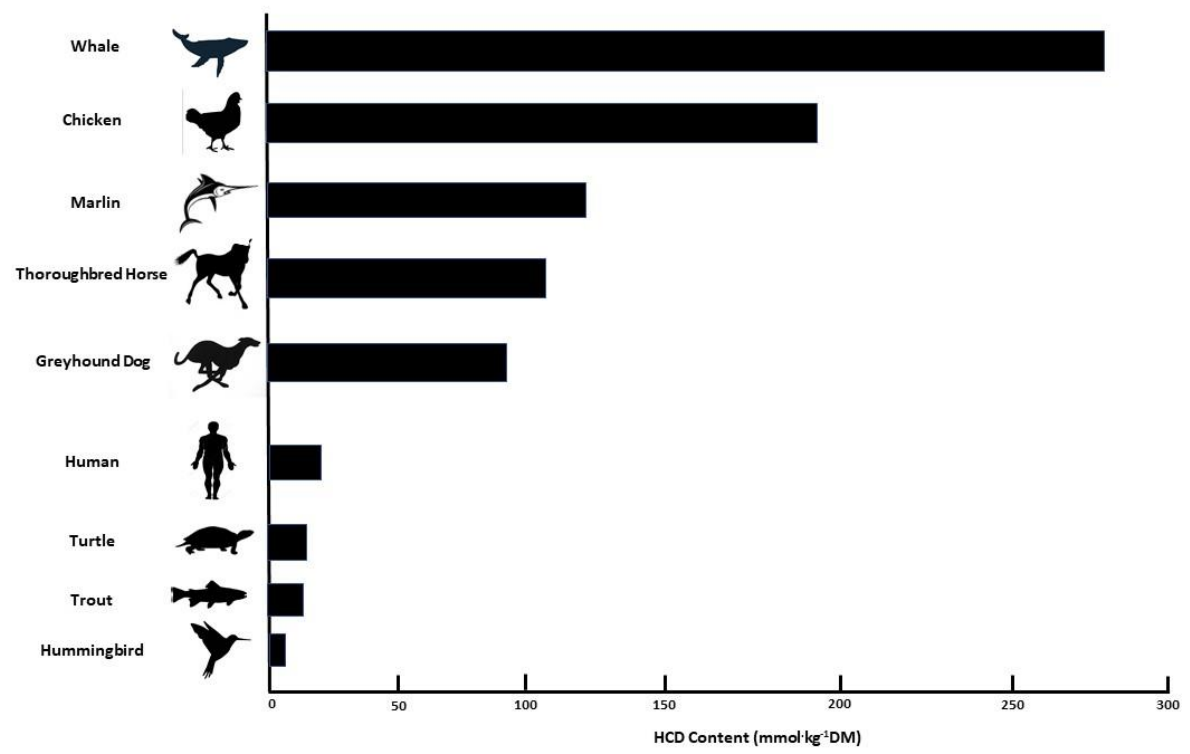

280 Figure 2: Skeletal muscle HCD content of various species

Note: The contents shown are indicative, and likely to vary based upon species sub-type and on the muscle type. More detailed overviews of HCD variation in different species are provided elsewhere 
bioRxiv preprint doi: https://doi.org/10.1101/2021.05.31.446418; this version posted May 31, 2021. The copyright holder for this preprint (which was not certified by peer review) is the author/funder, who has granted bioRxiv a license to display the preprint in perpetuity. It is made available under aCC-BY-ND 4.0 International license.

Declarations:

285 The is work was partially funded by a National Science Foundation CAREER grant (1253939) awarded 286 to Daniel Warren. Eimear Dolan (2019/05616-6 and 2019/26899-6), Bryan Saunders (2016/50438-0) 287 and Bruno Gualano (2017/13552-2) are financially supported by the Fundação de Ampara a Pesquisa 288 do Estado do São Paulo (FAPESP). Bryan Saunders has received a grant from Faculdade de Medicina 289 da Universidade de São Paulo (2020.1.362.5.2). None of the authors have any conflict of interest to 290 declare. 


\section{REFERENCES:}

1. Hamm L, Nakhoul N, Hering-Smith K. Acid-Base Homeostasis. Clin J Am Soc Nephrol. 2015;10(12):2232-22.

2. Hochachka P, Mommsen T. Protons and anaerobiosis. Science (80- ). 1983;219(4591):1391-7.

3. Robergs RA. Biochemistry of exercise-induced metabolic acidosis. AJP Regul Integr Comp Physiol. 2004;287(3):R502-16.

4. Jubrias SA, Crowther GJ, Shankland EG, Gronka RK, Conley KE. Acidosis inhibits oxidative phosphorylation in contracting human skeletal muscle in vivo. J Physiol. 2003;553(2):589-99.

5. Sahlin K, Harris R, Hultman E. Creatine kinase equilibrium and lactate content compared with muscle $\mathrm{pH}$ in tissue samples obtained after isometric exercise. Biochem J. 1975;152(2):17380.

6. Thomas C, Bishop DJ, Lambert K, Mercier J, Brooks GA. Effects of acute and chronic exercise on sarcolemmal MCT1 and MCT4 contents in human skeletal muscles: current status. AJP Regul Integr Comp Physiol. 2012;302(1):R1-14.

7. Jones R, Morris M. Monocarboxylate transporters: therapeutic targets and prognostic factors in disease. Clin Pharmacol Ther. 2016;100(5):454-63.

8. Bate Smith E. The buffering of muscle in rigor: Protein, phosphate and carnosine. J Physiol. 1938;92:336-43.

9. Pan J, Hamm J, Hetherington $\mathrm{H}$, Rothman $\mathrm{D}$, Shulman R. Correlation of lactate and $\mathrm{pH}$ in human skeletal muscle after exercise by 1H NMR. Magnestic Reson Med. 1991;20(1):57-65.

10. Sahlin $\mathrm{K}$, Harris $\mathrm{R}$, Nylind $\mathrm{B}$, Hultman E. Lactate content and $\mathrm{pH}$ in muscle obtained after dynamic exercise. Pflugers Arch Eur J Physiol. 1976;367(2):143-9.

11. Boldyrev A, Aldini G, Derave W. Physiology and pathophysiology of carnosine. Physiol Rev. 2013;93(4):1803-45.

12. Abe H. Role of histidine-related compounds as intracellular proton buffering constituents in vertebrate muscle. Biochem. 2000;65(7):757-65.

13. Dolan E, Saunders B, Harris R, et al. Comparative physiology investigations support a role for histidine-containing dipeptides in intracellular acid-base regulation of skeletal muscle. Comp Biochem Physiol Part A Mol Integr Physiol. 2019;234:77-86.

14. Harris RC, Marlin DJ, Dunnett M, Snow DH, Hultman E. Muscle buffering capacity and dipeptide content in the thoroughbred horse, greyhound dog and man. Comp Biochem Physiol - A Physiol. 1990;97(2):249-51.

15. Dolan E, Saunders B, Dantas W, et al. A comparative study of hummingbirds and chickens provides mechanistic insights into the histidine containing dipeptide role in skeletal muscle metabolism. Sci Rep. 2018;8(1):14788.

16. Plowman JE, Close EA. An evaluation of a method to differentiate the species of origin of meats on the basis of the contents of anserine, balenine and carnosine in skeletal muscle. $J$ Sci Food Agric. 1988;45(1):69-78.

17. Davey CL. The significance of carnosine and anserine in striated skeletal muscle. Arch Biochem Biophys. 1960;89(2):303-8.

18. Ultsch $\mathrm{G}$, Jackson D. Long-term submergence at 3 degrees $\mathrm{C}$ of the turtle Chrysemys picta 
bellii in normoxic and severely hypoxic water. III. Effects of changes in ambient PO2 and subsequent air breathing. J Exp Biol. 1982;97:87-99.

19. Odegard D, Sonnenfelt M, Bledsoe J, Keenan S, Hill C, Warren D. Changes in the material properties of the shell during simulated aquatic hibernation in the anoxia-tolerant painted turtle. J Exp Biol. 2018;22(18):176990.

20. Jackson D. Hibernating without oxygen: physiological adaptations of the painted turtle. J Physiol. 2002;543(3):731-7.

21. Warren $D$, Jackson D. Lactate metabolism in anoxic turtles: an integrative review. J Comp Physiol B. 2008;178(2):133-48.

22. Warren $D$, Jackson D. Effects of temperature on anoxic submergence: skeletal buffering, lactate distribution, and glycogen utilization in the turtle, Trachemys scripta. Am J Physiol Regul Integr Comp Physiol. 2007;293(1):458-67.

23. Jackson D. How a turtle's shell helps it survive prolonged anoxic acidosis. News Physiol Sci. 2000;15:181-5.

24. Reeves R. An imidazole alphastat hypothesis for vertebrate acid-base regulation: tissue carbon dioxide content and body temperature in bullfrogs. Respir Physiol. 1972;14(1):219-36.

25. Burton R. Temperature and acid-base balance in ectothermic vertebrates: the imidazole alphastat hypotheses and beyond. J Exp Biol. 2002;205(23):3587-600.

26. Saunders B, Franchi M, de Oliveira L, et al. 24-Week $\beta$-alanine ingestion does not affect muscle taurine or clinical blood parameters in healthy males. Eur J Nutr. 2020;59(1):57-65.

27. Mora L, Sentendreu M, Toldra F. Hydrophilic chromatographic determination of carnosine, anserine, balenine, creatine, and creatinine. J Agric Food Chem. 2007;55(12):4664-9.

28. Saunders B, De Salles Painelli V, De Oliveira LF, et al. Twenty-four weeks of B-alanine supplementation on carnosine content, related genes, and exercise. 2017. 896-906 p.

29. Amrhein $\mathrm{V}$, Korner-Nievergelt $F$, Roth $\mathrm{T}$. The earth is flat $(p>0.05)$ : significance thresholds and the crisis of unreplicable research. Peer J. 2017;5:e3544.

30. Wasser J, Jackson D. Effects of anoxia and graded acidosis on the levels of circulating catecholamines in turtles. Respir Physiol. 1991;84(3):363-77.

31. Jackson D, Heisler N. Intracellular and extracellular acid-base and electrolyte status of submerged anoxic turtles at 3 degrees C. Respir Physiol. 1983;53(2):187-201.

32. Hitzig B, Perng $W$, Burt T, Okunieff $P$, Johnson D. 1 H-NMR measurement of fractional dissociation of imidazole in intact animals. Am J Physiol. 1994;266(3 Pt 2):R1008-15.

33. Crush K. Carnosine and related substances in animal tissues. Comp Biochem Physiol. 1970;34(1):3-30.

34. Blomberg S, Baldwin J. Non-bicarbonate intracellular pH buffering of reptilian muscle. J Comp Physiol B. 1991;161:101-7.

35. Olson J, Crawford K. The effect of seasonal acclimatization on the buffering capacity and lactate dehydrogenase activity in tissues of the freshwater turtle chrysemys picta marginata. $J$ Exp Biol. 1989;145:471-6.

36. Noren S. Buffering capacity of the locomotor muscle in cetaceans: Correlates with postpartum development, dive duration and swim performance. Mar Mammal Sci. 
2004;20(4):808-22.

37. Spelnikov D, Harris R. A kinetic model of carnosine synthesis in human skeletal muscle. Amino Acids. 2019;51(1):115-21.

38. Rezende NS, Swinton P, de Oliveira LF, et al. The Muscle Carnosine Response to Beta-Alanine Supplementation: A Systematic Review With Bayesian Individual and Aggregate Data E-Max Model and Meta-Analysis [Internet]. Front Physiol. 2020;11 doi:10.3389/fphys.2020.00913.

39. Granger D, Kvietvys P. Reperfusion injury and reactive oxygen species: The evolution of a concept. Redox Biol. 2015;6:524-51.

40. Boldyrev A, Abe H, Stvolinsky S, Tyulina O. Effect of carnosine and related compounds on generation of free radical species: a comparative study. Comp Biochem Physiol Part $B$. 1995;112:481-5.

41. Boldyrev A, Abe H. Metabolic transformation of neuropeptide carnosine modifies its biological activity. Cell Mol Neurobiol. 1999;19(1):163-75. 